\title{
Program Bimbingan Dan Konseling Komprehensif Untuk Mengembangkan Standar Kompetensi Siswa
}

\author{
Caraka Putra Bhakti \\ Program Studi Bimbingan dan Konseling, Universitas Ahmad Dahlan \\ Correspondence email.caraka.pb@bk.uad.ac.id
}

\begin{abstract}
Abstrack: Tujuan artikel adalah mengkaji bagaimana pengembangan program bimbingan dan konseling komprehensif untuk mengembangkan standar kompetensi siswa. Metode kajian menggunakan analisis literatur. Keberhasilan implementasi Program bimbingan dan konseling komprehensif yaitu terpenuhinya enam ciri yaitu holistik, sistematik, seimbang, proaktif, integrasi dalam kurukulum sekolah, dan refleksi. Program Bimbingan dan konseling komprehensif didasarkan pada upaya pencapaian tugas perkembangan, pengembangan potensi, dan pengentasan masalah-masalah konseli. Standar kompetensi siswa di Indonesia mengacu pada Standar Kompetens Kemandirian Peserta Didik (SKKPD) yang terbagi dalam 11 aspek perkembangan. Prosedur dalam penyusunan program bimbingan dan konseling komprehensif adalah perencanaan, pengorganisasian, penerapan, dan evaluasi. Implikasi terhadap guru bimbinagn dan konseling pada implementasi program bimbingan dan konseling yaitu penguiatan pengetahuan yang utuh tentang teori perkembangan. Ketrampilan yang dimiliki konselor adalah melakukan koordinasi dengan berbagai pihak dalam melaksanakan program bimbingan dan konseling. Konselor memiliki kepemimpinan yang kokoh dalam menjalankan program bimbingan, serta memiliki ketrampilan manajemen waktu yang proporsional yaitu $80 \%$ waktu layanan bimbingan dan konseling bersifat direktif pada peserta didik sedangkan 20\% waktu layanan untuk kegiatan manajemen progran dan dukungan sistem.
\end{abstract}

Kata kunci: program, bimbingan, konseling, komprehensif, standar, kompetensi

\begin{abstract}
The purpose of this article is to examine how the development of comprehensive counseling and counseling programs to develop student competency standards. The study method uses literature analysis. Successful implementation of comprehensive guidance and counseling program is the fulfillment of six characteristics, namely holistic, systematic, balanced, proactive, integration in school curriculum, and reflection. Developmental tasks are formulated as competency standards to be achieved by counselors, so this approach is also called standard-based guidance and counseling. Standard of student competence in Indonesia refers to Standards of Independence Competence Learners (SKKPD) which is divided into 11 aspects of development. Procedures in the preparation of comprehensive guidance and counseling programs are planning, organizing, implementing, and evaluating. Implications of guidance and counseling teachers on the implementation of guidance and counseling programs are intimate knowledge acquisition of developmental theories. Counselor's skills are to coordinate with various parties in implementing guidance and counseling program. The counselor has a strong leadership in running the guidance program, and has a proportional time management skills that is $80 \%$ of the time counseling and guidance services are directive in the learner while $20 \%$ of the service time is for the management and system support activities
\end{abstract}

Keyword: programs, guidance, counseling, comprehensive, standards, competencies 


\section{PENDAHULUAN}

Bimbingan, sebagai upaya pendidikan, diartikan sebagai proses bantuan kepada individu untuk mencapai tingkat perkembangan diri secara optimum di dalam navigasi hidupnya secara mandiri. Bantuan dalam arti bimbingan yaitu memfasilitasi individu untuk mengembangkan kemampuan memilih dan mengambil keputusan atas tanggung jawab sendiri. Kondisi perkembangan optimum adalah kondisi dinamis yang ditandai dengan kesiapan dan kemampuan individu untuk memperbaiki diri (self-improvement) agar dia menjadi pribadi yang berfungsi penuh (fully-fungctioning) di dalam lingkungannya (Sunaryo Kartadinata, 2011:57)

Asumsi dasar pendekatan Bimbingan dan konseling perkembangan adalah pemikiran bahwa perkembangan individu yang sehat akan terjadi dalam interaksi yang sehat individu dengan lingkungannya. Dengan kata lain, lingkungan tersebut bagi individu menjadi lingkungan belajar. "Being educate for its proportional emphasis is on prevention and improvement, not corective and therapeutic, Being developmental for its main goal of counseling is to develop humaan capacity by providing developmental environment" (Myrick, 2011). Kata sehat dalam hal ini bukan hanya merujuk pada interaksi antara individu dan lingkungan, tetapi lingkungan itu sendiri juga harus sehat.

Menurut tim penulis buku Penataan Pendidikan Profesional Konselor dan Layanan bimbingan dan Konseling dalam Jalur Pendidikan Formal, (2008:194) pada saat ini telah terjadi perubahan paradigma pendekatan bimbingan dan konseling, yaitu dari pendekatan yang berorientasi tradisional, remedial, klinis, dan terpusat pada konselor, kepada pendekatan yang berorientasi perkembangan dan preventif. Pendekatan bimbingan dan konseling perkembangan (Developmental Guidance and Counseling) atau bimbingan dan konseling komprehensif (Comprehensive Guidance and Counseling) didasarkan pada upaya pencapaian tugas perkembangan, pengembangan potensi, dan pengentasan masalah-masalah konseli. Tugas-tugas perkembangan dirumuskan sebagai standar kompetensi yang harus dicapai konseli, sehingga pendekatan ini disebut juga bimbingan dan konseling berbasis standar (Standard Based Guidance and Counseling). Ketika pendekatan bimbingan dan konseling perkembangan dipergunakan akan menggabungkan pendekatan yang berorientasi klinis, remidial, dan preventif, (Myrick, 2011:8).

Myrick (2011:33) bimbingan dan konseling perkembangan berasumsi bahwa secara lahiriah manusia menggerakkan kepribadian individualnya secara berurutan dan secara positif menuju pengembangan diri. Ini membuat kita mengenali bahwa terdapat suatu kekuatan antara kita satu sama lain yang membuat kita meyakini bahwa kita adalah istimewa dan tidak ada orang yang menyerupai kita. Ini juga berasumsi bahwa potensi individual kita merupakan asset yang bernilai bagi masyarakat dan masa depan kemanusiaan.

Uman Suherman (2011:5) Bimbingan komprehensif merupakan pandangan mutakhir yang bertitik tolak dari asumsi yang positif tentang potensi manusia. Berdasarkan asumsi inilah bimbingan dipandang sebagai suatu proses memfasilitasi perkembangan yang menekankan kepada upaya membantu semua peserta didik dalam semua fase perkembangannya. Selama ini bimbingan sering dipandang sebagai kegiatan layanan yang mengedepankan penyembuhan atau pemecahan masalah. Padahal selain itu bimbingan berfungsi pencegahan, pendidikan dan pengembangan. Bimbingan komprehensif diartikan sebagai sebuah program layanan bantuan yang mengandung prinsip-prinsip : 1) Subjek layanan adalah semua peserta didik; 2) fokus pada kegiatan pembelajaran peserta didik dan mendorong perkembangan peserta didik; 3) konselor dan guru merupakan fungsionaris yang bekerja sama; 4) program bimbingan terorganisir dan terencana sebagai bagian vital dari bimbingan komprehensif; 5) peduli kepada penerimaan diri, pemahaman diri, dan peningkatan diri; 6) memfokuskan pada proses; 7) berorientasi taem work dan mensyaratkan pelayanan dari konselor profesional yang terlatih; 8) bersifat fleksibel dan sekuensial.

Pengembangan dan implementasi dari program bimbingan dan konseling komprehensif berkembang secara cepat di Amerika. Penelitian Martin, Carey, dan De Coster (dalam Gysbrers 2012:27) menemukan, "bahwa baru 17 negera bagian memiliki model program yang tetap, 24 negera bagian dalam proses implementasi model program, dan 10 negera bagian masih pada tahap awal pengembangan model".

Seiring dengan perkembangan ilmu bimbingan dan konseling di Amerika, model 
program bimbingan dan konseling komprehensif di adopsi di beberapa negara di ASEAN. Menurut Hasan dan Bhakti (2016) negaran Malaysia mengimplementasikan model program bimbingan dan konseling komprehensif di sekolah-sekolahnya. Perkembangan Program bimbingan dan konseling komprehensif mulai banyak dibicarakan dalam forum ilmiah serta dengan didukung Permendiknas No.27 Tahun 2008, program layanan bimbingan konseling di Indoensia mengarah pada pendekatan yang komprehensif. Pendekatan ini dipilih karena didukung beberapa hasil penelitian tentang efektifitas bimbingan komprehensif dalam meningkatkan mutu pendidikan. Bimbingan konseling komprehensif mampu memberikan kontribusi yang positif bagi pengembangan akademik, pribadi, sosial, dan karir siswa di sekolah. Bimbingan komprehensif juga mampu menciptakan iklim belajar yang kondusif bagi siswa di sekolah.

Wilkerson, K., Pérusse, R., \& Hughes, A. (2013) penelitian tentang konselor sekolah, program bimbingan konseling komprehensif dan prestasi akademik, hasil penelitian menunjukkan dukungan program bimbingan dan koseling komprehensif memiliki kontribusi yang signifikan dalam meningkatkan pretasi siswa, ada semkin banyak bukti konselor dapat menggunakan intervensi strategis untuk meningkatkan prestasi akademik. Penelitian oleh Young, A., \& Kaffenberger, C. (2011) tentang Keyakinan dan praktik konselor sekolah yang menggunakan data untuk menerapkan program konseling sekolah yang komprehensif, hasilnya menunjukkan bahwa konselor sekolah yang telah mendapatkan pelatihan penggunaan data , sangan memahami pentingnya menggunakan data untuk memberikan layanan kepada siswa dan mendorong evaluasi dan perbaikan program. Partisipasi siswa meingkatkan seiring dampak positif pada praktik data serta meningkatkan kepercayaan konselor sekolah tentang pentingnya menggunakan data.

$$
\text { Hidayat dan Herdi (2013) }
$$

mengungkapkan bahwa model bimbingan dan konseling komprehensif dirancang untuk merespons berbagai persoalan yang dihadapi oleh konselor sekolah. Model ini dikembangkan berdasarkan berbagai hasil kajian teori, dan hasil penelitian yang telah dilaksanankan oleh ASCA tentang program bimbingan dan konseling dan profesi konselor sekolah. Model ini merupakan alternatif model bimbingan dan konseling yang memberikan kesempatan bagi akademisi dan praktisi konseling untuk meningkatkan layanan bimbingan dan konseling di sekolah.

Meskipun model ini diadopsi dari model ASCA yang dikembangkan untuk mengatasi masalah yang dialami oleh bimbingan dan konseling di Amerika Serikat, namun model ini dapat diadaptasikan di Indonesia. Model bimbingan dan konseling komprehensif memberikan kesempatan bagi ilmu bimbingan dan konseling di Indonesia melakukan perubahan ke arah yang lebih baik. Adaptasi model bimbingan dan konseling komprehensif memberi peluang kepada konselor untuk mneunjukkan kinerjanya, sehingga profesi bimbingan dan konseling mendapatkan pengakuan di masyarakat.

Model bimbingan dan konseling komprehensif versi Amerika yang adopsi di Indonesia, pemerintah Indonesia melalui kementrian pendidikan mengeluarkan Permendikbud Nomor 111 Tahun 2014 tentang Bimbingan dan Konseling Pada Pendidikan Dasar dan Pendidikan Menengah. Substansi dari permendikbud ini meliputi komponen program, bidang layanan, struktur program layanan, serta kegiatan dan alokasi waktu. Permendikbud tidak secara eksplisit membahas tentang bimbingan dan konseling komprehensif, tetapi dilihat dari substansinya ini menunjukkan versi model bimbingan dan konseling komprehensif.

Pada kenyatannya hasil penelitian Bhakti dkk (2017) tentang pemahaman guru bimbingan dan konseling tingkat SMP di kabupaten Gunungkidul tentang program bimbingan dan konseling komprehensif menunjukkan bahwa belum semua guru BK memiliki pemahaman yang baik tentang program bimbingan dan konseling komprehensif. Pada jenjang SMK, penelitian oleh Kumara (2015) Pemahaman guru bimbinga di Bantul pada ketegori sedang tentang manajemen bimbingan dan konseling komprehensif. Penelitian lain oleh Daryono (2014) pemahaman guru bimbingan dan konseling tingkat SMA tentang pogram bimbingan dan konseling komprehesniof mayoritas di Magelang dalam kategori sedang. Sehingga perlu ada upaya yang implementatif dalam pengembangan kompetensi guru bimbingan dan konseling dalam pengembangan program bimbingan dan konseling komprehensif.

Dengan demikian, guru BK/konselor sangat diharapkan mampu mengembangkan layanan bimbingan dan konseling komprehensif. 
Menurut Rizkiyah (2017) Faktor penting yang berpengaruh terhadap operasionalisasi Permen Dikbud No 111 Tahun 2014 yang menegaskan implementasi program bimbingan dan konseling komprehensif adalah pengawasan, walaupun telah dilakukan sosialisasi dan pelatihan kepada guru BK tetapi bila tidak ada tindak lanjut monitoring ke sekolah maka tidak akan terealisasi dengan baik

Dari perspektif tersebut di atas, penulis membahas bagaimana implementasi program bimbingan dan konseling komprehensif dan analisis mengembangkan standar kompetensi siswa.

\section{Standar Kompetensi Siswa}

Layanan bimbingan dan konseling pada dasarnya bertujuan pada pencapaian suatu standar yang telah ditentukan. seperti ASCA (2012:29) merekomendasikan tiga area untuk belajar siswa sebagai belajar dalam layanan bimbingan dan konseling di Amerika sebagai berikut:

1. Pengembangan akademik, standar yang berfokus kegiatan program bimbingan dan konseling pada implementasi strategi layanan untuk mengembangkang kemampuan siswa dalam belajar

2. Pengembangan karir, yaitu standar dalam program bimbingan dan konseling untuk membantu siswa dalam 1) memahami hubungan sekolah dengan dunia kerja, 2) merencanakan dan membuat transisi yang berhasil dari sekolah ke sekolah lanjutan dan atau dunia kerja dan dari pekerjaan ke pekerjaan lainnya sepajang kehidupannya

3. Pengembangan Sosial/Emosional, yaitu standar dalam program bimbingan dan konseling dalam membantu siswa dalam mengatur emosi dan belajar dan mampu mengaplikasikan ketrampilan interpersonal

Tujuan program bimbingan dan konseling komprehensif yang sistemik adalah untuk mengatasi kesenjangan antara standar kompetensi siswa yang akan dicapai dan kemampuan para siswa yang sebenarnya di sekolah atau di wilayah tertentu. Untuk menyusun standar kompetensi siswa dimulai dengan meninjau tujuan pendidikan sekolah dan negara anda. Tujuan pendidikan tersebut sering akan mencakup isi bimbingan dan konseling berfokus pada topik-topik seperti prestasi akademik, pengembangan karir, dan pengembangan pribadi-sosial. Periksa literatur profesional dan relevan profesional pernyataan posisi asosiasi. meninjau kebudayaan dan gender, dan isu-isu lokal yang dapat diindentifikasi menjadi standar kompetesi siswa (Gysbers,2012:65).

Standar kompetensi siswa perlu diidentifikasi lebih awal karena ini adalah tujuan dari program bimbingan dan konseling komprehensif. Untuk menyusun standar kompetensi siswa ini perlu di analisis tujuan pendidikan nasional di Indonesia serta tujuan institusional sekolah. Undang-Undang No. 20, Tahun 2003. Pasal 3 menyebutkan, "Pendidikan nasional berfungsi mengembangkan kemampuan dan membentuk watak serta peradaban bangsa yang bermartabat dalam rangka mencerdaskan kehidupan bangsa, bertujuan untuk berkembangnya potensi peserta didik agar menjadi manusia yang beriman dan bertakwa kepada Tuhan Yang Maha Esa, berakhlak mulia, sehat, berilmu, cakap, kreatif, mandiri, dan menjadi warga negara yang demokratis serta bertanggung jawab.

Sebagai perbandingan di Amerika yang standar kompetensi siswa dibagi ke dalam tiga bidang (domain) yaitu akademik, pribadi/sosial, dan karir (ASCA, 2012:29), sedangkan Florida (2010:20) mengemukakan empat bidang pengembangan (domain) yaitu akademik, karir, pribadi sosial, dan Keterlibatan dalam Komunitas dan Perkembangan Kewarganegaraan Global. Sedangkan Utah (Gysbers,2012:66) pengembangan standar kompetensinya menjadi empat bidang yaitu pengembangan akademik/pembelajaran, pengembangam karir, pengembangan Multibudaya/ warga global, dan pengembangan pribadi sosial.

Pengembangan standar kompetensi siswa di Indoesia tidak akan sama dengan negera lain. Untuk standar kompetensi siswa di Indonesia disesuaikan dengan tujuan pendidikan nasional, dan budaya Indonesia.

Tugas perkembangan peserta didik/konseli yang telah teridentifikasi sebelumnya perlu dikembangkan lebih lanjut dalam bentuk standar kompetensi. Dalam layanan bimbingan dankonseling, standar kompetensi tersebut dikenal dengan istilah Standar Kompetensi Kemandirian Peserta Didik (SKKPD). Berbagai aspek perkembangan yang terdapat dalam SKKPD pada dasarnya dirujuk dari tugas perkembangan yang akan dicapai oleh peserta didik/konseli. Dengan demikian, antara tugas perkembangan dan aspek perkembangan yang 
terdapat dalam SKKPD memiliki keterkaitan yang sangat erat.

Tabel berikut ini mendeskripsikan keterkaitan antara tugas perkembangan dengan SKKPD yang dikutip dari Panduan Operasional Penyelenggaraan Bimbingan dan Konseling Sekolah Menengah Atas (2016:14) sebagai berikut

Tabel 1. keterkaitan antara tugas perkembangan dengan SKKPD

\begin{tabular}{|c|c|c|}
\hline No & $\begin{array}{c}\text { Tugas } \\
\text { perkembangan }\end{array}$ & $\begin{array}{c}\text { Aspek } \\
\text { Perkembangan } \\
\text { dalam SKKPD }\end{array}$ \\
\hline 1 & $\begin{array}{l}\text { Mencapai } \\
\text { perkembangan diri } \\
\text { sebagai remaja yang } \\
\text { beriman dan } \\
\text { bertakwa kepada } \\
\text { Tuhan Yang Maha } \\
\text { Esa }\end{array}$ & $\begin{array}{l}\text { Landasan hidup } \\
\text { religius }\end{array}$ \\
\hline 2 & $\begin{array}{l}\text { Mengenal sistem } \\
\text { etika dan nilai-nilai } \\
\text { bagi pedoman hidup } \\
\text { sebagai pribadi, } \\
\text { anggota masyarakat, } \\
\text { dan minat manusia }\end{array}$ & $\begin{array}{l}\text { Landasan perilaku } \\
\text { etis }\end{array}$ \\
\hline 3 & $\begin{array}{l}\text { Mengenal gambaran } \\
\text { dan mengembangkan } \\
\text { sikap tentang } \\
\text { kehidupan mandiri } \\
\text { secara emosional, } \\
\text { sosial, dan ekonomi }\end{array}$ & Kematangan emosi \\
\hline 4 & $\begin{array}{l}\text { Mengembangkan } \\
\text { pengetahuan dan } \\
\text { keterampilan sesuai } \\
\text { dengan } \\
\text { kebutuhannya untuk } \\
\text { mengikuti dan } \\
\text { melanjutkan } \\
\text { pelajaran dan/atau } \\
\text { mempersiapkan } \\
\text { karier serta berperan } \\
\text { dalam } \\
\text { kehidupan } \\
\text { masyarakat } \\
\end{array}$ & $\begin{array}{l}\text { Kematangan } \\
\text { intelektual }\end{array}$ \\
\hline 5 & Memantapkan nilai & Kesadaran \\
\hline
\end{tabular}

Menurut Panduan Operasional

Penyelenggaraan Bimbingan dan Konseling Sekolah Menengah Atas (2016:14) aspek-aspek perkembangan dalam SKKPD selanjutnya

\begin{tabular}{|c|c|c|}
\hline & $\begin{array}{l}\text { dan cara bertingkah } \\
\text { laku yang dapat } \\
\text { diterima dalam } \\
\text { kehidupan sosial } \\
\text { yang lebih luas }\end{array}$ & $\begin{array}{l}\text { tanggung jawab } \\
\text { sosial }\end{array}$ \\
\hline 6 & $\begin{array}{l}\text { Mencapai pola } \\
\text { hubungan yang baik } \\
\text { dengan teman sebaya } \\
\text { dalam peranannya } \\
\text { sebagai pria atau } \\
\text { wanita }\end{array}$ & Kesadaran gender \\
\hline 7 & $\begin{array}{l}\text { Mempersiapkan diri, } \\
\text { menerima dan } \\
\text { bersikap positif serta } \\
\text { dinamis terhadap } \\
\text { perubahan fisik dan } \\
\text { psikis yang terjadi } \\
\text { pada } \\
\text { diri sendiri untuk } \\
\text { kehidupan yang } \\
\text { sehat }\end{array}$ & Pengembangan diri \\
\hline 8 & $\begin{array}{l}\text { Memiliki } \\
\text { kemandirian perilaku } \\
\text { ekonomis }\end{array}$ & $\begin{array}{l}\text { Perilaku } \\
\text { kewirausahaan } \\
\text { (kemandirian } \\
\text { perilaku ekonomis) }\end{array}$ \\
\hline 9 & $\begin{array}{l}\text { Mengenal } \\
\text { kemampuan, bakat, } \\
\text { minat, serta arah } \\
\text { kecenderungan karier } \\
\text { dan apresiasi seni } \\
\end{array}$ & $\begin{array}{l}\text { Wawasan dan } \\
\text { kesiapan karier }\end{array}$ \\
\hline 10 & $\begin{array}{l}\text { Mencapai } \\
\text { kematangan } \\
\text { hubungan dengan } \\
\text { teman sebaya }\end{array}$ & $\begin{array}{l}\text { Kematangan } \\
\text { hubungan dengan } \\
\text { teman sebaya }\end{array}$ \\
\hline 11 & $\begin{array}{l}\text { Mencapai } \\
\text { kematangan dalam } \\
\text { kesiapan diri } \\
\text { menikah dan hidup } \\
\text { berkeluarga }\end{array}$ & $\begin{array}{l}\text { Kesiapan diri untuk } \\
\text { menikah dan } \\
\text { berkeluarga }\end{array}$ \\
\hline
\end{tabular}

menjadi rumusan kompetensi yang dirujuk oleh konselor/guru bimbingan dan konseling dalam mempersiapkan rancangan pelaksanaan dari berbagai kegiatan layanan bimbingan dan konseling. Rumusan kompetensitersebut 
dikembangkan lebih rinci menjadi tugas-tugas perkembangan yang harus dicapai oleh peserta didik/konseli dalam berbagai tataran internalisasi

\section{Program Bimbingan Konseling Komprehensif}

ASCA (2012:vii) Program konseling sekolah yang komprehensif merupakan komponen integral dari misi akademik sekolah program konseling sekolah komprehensif, didorong oleh data siswa dan berdasarkan standar akademik, karir dan / pembangunan sosial personal, mempromosikan dan meningkatkan proses pembelajaran untuk semua peserta didk.

Program konseling sekolah yang efektif merupakan upaya kolaboratif antara konselor sekolah, orang tua dan pendidik lainnya untuk menciptakan lingkungan yang mengembangkan prestasi belajar siswa. Lebih lanjut menurut Bowers \& Hatch (Fathur Rahman, 2002:7) menyatakan bahwa program bimbingan dan konseling sekolah tidak hanya bersifat komprehensif dalam ruang lingkup, namun juga harus bersifat preventif dalam desain, dan bersifat pengembangan dalam tujuan (comprehensive in scope, preventive in design and developmental in nature). Pertama, bersifat komprehensif berarti program bimbingan dan konseling harus mampu memfasilitasi capaiancapaian perkembangan psikologis siswa dalam totalitas aspek bimbingan (pribadi-sosial, akademik, dan karir)

Layanan bimbingan dan konseling di tujukan untuk seluruh siswa tanpa syarat apapun. Kedua, bersifat preventif dalam disain mengandung arti bahwa pada dasarnya tujuan pengembangan program bimbingan dan konseling di sekolah hendaknya dilakukan dalam bentuk yang bersifat preventif. Upaya pencegahan dan antisipasi sedini mungkin (preventive education) hendaknya menjadi semangat utama yang terkandung dalam pelayanan dasar (guidance curriculum) yang diterapkan sekolah. Melalui cara yang preventif tersebut diharapkan siswa mampu memilah tindakan dan sikap yang tepat dan mendukung pencapaian perkembangan psikologis kearah ideal dan positif. Ketiga, bersifat pengembangan dalam tujuan bahwa program yang didisain konselor sekolah bertujuan untuk memenuhi kebutuhan para peserta didik sesuai dengan tahap perkembangan.

Sugiyo 2014:15) bimbingan dan konseling komprehensif diprogramkan untuk tujuan, yaitu pengenalan, akomodasi, dan tindakan.

semua peserta didik hukumnya wajib memperoleh layanan bimbingan dan konseling, sehingga image/persepsi bahwa fokus bimbingan dan konseling hanyalah siswa yang bermasalah saja akan hilang. Oleh karena itu dalam bimbingan dan konseling komprehensif perlu memperhatikan : (1) ruang lingkup menyeluruh, (2) dirancang untuk lebiih berorientasi pada pencegahan, (3) tujuannya pengembangan potensi peserta didik.

Dalam penyusunan program bimbingan dan konseling komprehensif, harus memahami desain dan cara implemantasinya. Dollarhide (2011:51) menegaskan untuk menjadi komprehensif, program bimbingan dan konseling harus memiliki ciri sebagai berikut :

Holistik. Program bimbingan dan konseling komprehensif berorientasi pada upaya pengembangan seluruh aspek perkembangan siswa, tanpa terkecuali. Bidang yang dikembangkan adalah bidang akademik, karir, dan pribadi-sosial.

Sistematik. Untuk memfasilitasi perkembangan siswa yang optimal dipengaruhi oleh sistem lingkungan. Sistematik yang dimaksud adalah seluruh aktivitas layanan bimbingan tersusun secara sistematik, dimana dalam prosesnya melibatkan semua elemen atau pihak terkait, yang signifikan dalam kehidupan siswa.

Seimbang. Seimbang dalam perspektif kompehensif adalah aktivitas konselor harus seimbang pada layanan dasar, perencanaan individual, dan layanan responsif, dan dukungan sistem. Keseimbangan juga terdapat antara waktu dan tugas utama konselor, seperti konseling, edukasi, konsultasi dan kolaborasi, kepemimpinan, koordinasi dan advokasi.

Proaktif. Proaktf dalam program bimbingan dan konseling komprehensif yaitu konselor proaktif terahadap masalah kemungkinan timbul yang dapat menghambat kesuksesan siswa melalui tindakan preventif.

Terintegrasi dalam kurukulum sekolah. Program bimbingan dan konseling komprehensif bukan bagian terpisah dari kurikulum sekolah, namun bagian dari kurikulum sekolah untuk mencapai visi dan misi sekolah. Program BK harus masuk dalam program sekolah, selaras dengan tujuan sekolah. 
Refleksi. Refleksi merupakan kegiatan untuk menganalisa efektivitas kerja konselor dan efektifitas program bimbingan dan konseling komprehensif. Kegiatan ini untuk mengetahui sejauhmana pengaruh layanan bimbingan dan konseling dalam kehidupan dan perkembangan siswa.

Schmidt (2008:90) prosedur dalam penyusunan program bimbingan dan konseling komprehensif adalah perencanaan (planning), pengorganisasian (organizing), penerapan (implementating), dan evaluasi (evaluation).

1. Perencanaan (Planning)

Proses Perencanaan program bimbingan dan konseling di sekolah, seharusnya dilakukan secara terbuka, bukan hanya guru bimbingan dan konseling, namun juga melibatkan seluruh pihak yang memiliki peran penting dalam pengambilan kebijakan. Schmidt (2008:90) pada tahap perencanaan yang dilakukan adalah berfokus pada prosedur kepemimpinan dan keputusan tentang schoolwide, mengadakan asesmen pada siswa, orang tua, dan guru, setelah itu merancang tujuan yang obyektif.

Florida (2010:45) pada tahap merancang program bimbingan ada beberapa hal yang dilakukan adalah sebagai berikut :

a. Menentukan tujuan program

b. Menentukan standar program

c. Penilaian sekolah dan kebutuhan siswa

d. Penilaian program saat ini

e. Identifikasi kompetensi siswa

f. Identifikasi kebutuhan dibandingkan kesenjangan sumber daya

g. Menentukan prioritas

2. Perancangan (Designing)

Sebagai arahan dalam penyusunan program bimbingan dan konseling komprehensif Gysbres (2012:140) ada enam tahap mewujudkan desain program BK sebagai berikut :

a. Menentukan struktur program dasar dari program yang akan disusun, termasuk menyusun struktur komponen dan menentukan komponen program.

b. Merancang kompetensi siswa berdasarkan isi wilayah dan tingkat sekolah.

c. Menegasan kembali dukungan kebijakan pengembangan program bimbingan dan konseling.

d. Menetapkan prioritas pada program delivery e. Menetapkan parameter untuk alokasi sumber daya program.

f. Menempatkan semua keputusan secara tertulis dan mendistribusikan pedoman pelaksanaan program kepada semua konselor dan para pengelola.

3. Penerapan (Implementating)

Gysbers (2012:224) beberapa rekomendasi aktualisasi program untuk perubahan, pemimpin program bimbingan dan konseling perlu mempertimbangkan sumberdaya personil, sumber daya keuangan dan sumber daya politik program bimbingan dan konseling

a. Sumberdaya Personil

1) Mengimplementasikan rasio jumlah siswa : konselor yang direkomendasikan. Untuk standart di Indoensia rasio konselor dengan siswa yaitu $1: 150$ siswa.

2) Mengembangkan deskripsi tugas konselor sekolah

3) Menetapkan tingkat peran dan tanggung jawab pemimpin program bimbingan dan konseling.

4) Mengembangkan deskrisi tugas untuk semua personil yang terlibat dalam program bimbingan dan konseling

5) Memperjelas hubungan dalam organisasi program bimbingan dan konseling.

b. Sumberdaya Keuangan

1) Menetapkan anggaran pada setiap bagian bimbingan

2) Mengekplorasi penggunaan sumber daya luar sekolah

3) Mengembangkan panduan sumberdaya komponen program bimbingan dan konseling.

4) Menetapkan fasilitas standar bimbingan.

c. Sumberdaya Politik

1) Memperbaharui kebijakan dan prosedur yang ada

2) Memunculkan dukungan dari tingkatan konselor, pengelola dam guru

3) Bekerja dengan resistan terhadap staff pendukung

4) Bekerja dengan unsur penting yaitu orang tua bersngkutansan,

4. Evaluasi (Evaluation)

Setelah pada tahap perencanaan dan perancangan program selesai, selanjtnya 
melangkah pada tahap implementasi program, maka tahap selanjutnya adalah evaluasi. Gysbers (2012:353) mendefinisikan evaluasi adalah kegiatan mengumpulkan dan menganalisis tentang program atau intervensi dengan cara tertib untuk membuat keputusan.

Pengembangan program bimbingan dan konseling komprehensif perlu dirancang secara jelas. Maka perlu disusun petunjuk dalam penyusunan program bimbingan dan konseling komprehensif. Pedoman ini berisi tentang bagaimana mengembangkan program bimbingan dan konseling komprehensif. Berikut adalah struktur pengembangan program bimbingan dan konseling komprehensif yang telah dikembangkan oleh ASCA yang telah dijelaskan pula dalam Lampiran Permendikbud Nomor 111 Tahun 2014.

1. Rasional

Perlu dirumuskan dasar pemikiran tentang urgensi bimbingan dan konseling dalam keseluruhan program satuan pendidikan. Rumusan konsep dasar kaitan antara bimbingan dan konseling dengan pembelajaran/implementasi kurikulum, dampak perkembangan iptek dan konteks sosial budaya hidup masyarakat (termasuk peserta didik), dan halhal lain yang dianggap relevan.

2. Visi dan Misi

Sjian visi dan misi bimbingan dan konseling harus sesuai dengan visi dan misi sekolah/madrasah, oleh karena itu sajikan visi dan misi sekolah/madrasah kemudian rumuskan visi dan misi program layanan bimbingan dan konseling.

3. Deskripsi Kebutuhan

Rumusan didasarkan atas hasil asesmen kebutuhan (need assessment) peserta didik/konseli dan lingkungannya ke dalam rumusan perilaku-perilaku yang diharapkan dikuasai peserta didik/konseli.

4. Tujuan Layanan Bimbingan dan Konseling Rumusan tujuan yang akan dicapai disusun dalam bentuk perilaku yang harus dikuasai peserta didik/ konseli setelah memperoleh layanan bimbingan dan konseling.

5. Komponen Program Bimbingan dan Konseling

Komponen program bimbingan dan konseling di satuan pendidikan meliputi: (1) Layanan Dasar, (2) Layanan Peminatanan peserta didik dan Perencanaan Individual
(3) Layanan Responsif, dan (4) Dukungan sistem.

6. Bidang Layanan Bimbingan dan Konseling Bidang layanan bimbingan dan konseling meliputi pribadi, sosial, belajar dan karir. Materi layanan bimbingan klasikal disajikan secara proporsional sesuai dengan hasil asesmen kebutuhan 4 (empat) bidang layanan.

7. Pengembangan Tema/Topik

Tema/topik ini merupakan rincian lanjut dari identifikasi diskripsi kebutuhan peserta didik dalam aspek perkembangan pribadi, sosial, belajar dan karir.

8. Pengembangan Rencana Pelaksanaan Layanan Bimbingan dan Konseling (RPLBK).

RPLBK dikembangkan sesuai dengan tema/topikdan sistematika yang diatur dalam panduan penyelenggaraan layanan bimbingan dan konseling pada satuan pendidikan.

9. Evaluasi, Pelaporan dan Tindak Lanjut

Rencana evaluasiperkembangan peserta didik/konseli didasarkan pada rumusan tujuan yang ingin dicapai dari layanan yang dilakukan. Di samping itu, perlu dilakukan evaluasi keterlaksanaan program, dan hasilnya sebagai bentuk akuntabilitas layanan bimbingan dan konseling. Hasil eveluasi harus dilaporkan dan diakhiri dengan rekomendasi tentang tindak lanjut pengembangan program selanjutnya.

10. Anggaran Biaya

Rencana anggaran biaya untuk mendukung implementasi program layanan bimbingan dan konseling disusun secara realistik dan dapat dipertanggungjawabkan secara transparan. Rancangan biaya dapat memuat kebutuhan biaya operasional layanan bimbingan dan konseling dan pengembangan profesi bimbingan dan konseling.

11. Rencana Operasional (Action Plan)

Rencana kegiatan (action plans) diperlukan untuk menjamin program bimbingan dan konseling dapat dilaksanakan secara efektif dan efesien. Rencana kegiatan adalah uraian detil dari program yang menggambarkan struktur isi program, baik kegiatan untuk memfasilitasi peserta didik/konseli mencapai kemandirian dalam kehidupannya. 


\section{IMPLIKASI BAGI GURU BK/KONSELOR}

Implementasi program bimbingan dan konseling diperlukan penguasaan konsep yang utuh dan keterampilan yang mumpuni. Menurut Galassi untuk menerapkan program bimbingan dan konseling komprehensif yang benar-benar konsisten dengan teori perkembangan membutuhkan konselor yang betul-betul terlatih dan menguasai teori perkembangan (Fajar Santohadi, 2010:32). Selain penguatan pada sisi pengetahuan, guru bimbingan dan konseling perlu dibekali seperangkat pelatihan yang mendalam dalam mengimplementasikan program bimbingan dan konseling komprehensif. Hail sejalan dengan hasil penelitian Burkard, A., Gillen, M., Martinez, M., \& Skytte, S. (2012) bahwa pelatihan praktik program bimbingan dan konseling komprehenisf efektif dalam meningkatkan implementasi program bimbingan dan konseling di sekolah menengah atas di Winconsin, Ammerika

Pada aspek keterampilan, yaitu guru bimbingan dan konseling/ konselor sebagai koordinator program bimbingan dan konseling. Proses pengembangan program bimbingan dan konseling memerlukan rencana yang dirancang dengan hati-hati dan hati-hati yang didasarkan pada kebutuhan dan lingkungan peserta didik. (Gysbers, 2012 : 63). Program bimbingan dan konseling merupakan bagian integral dari tujuan pendidikan sekolah dan negara. Untuk memastikan bahwa program bimbingan dan konseling dioptimalkan dan sesuai dengan tujuan sekolah, sangat penting bagi konselor sekolah untuk berperan aktif sebagai koordinator program bimbingan dan konseling.

Koordinasi sebagai intervensi konselor adalah proses manajemen bimbingan tidak langsung yang diberikan kepada masing-masing pembelajar yang berbeda yang mencakup kegiatan umum dan khusus. Kegiatan koordinasi meliputi pengumpulan data dan informasi, pengalokasian bahan dan sumber daya, persiapan dan pengorganisasian pertemuan, pengembangan dan operasi, pengawasan dan pemantauan lainnya, dan pemberian kepemimpinan yang efektif. (Myrick, 2011: 369).

Koordinasi adalah proses kepemimpinan seorang penasihat pada konselor lain dalam membantu mengatur, mengelola, dan mengevaluasi program bimbingan dan konseling di sekolah. Seorang konselor membantu orang tua untuk mendapatkan layanan yang dibutuhkan untuk anak-anak mereka melalui proses rujukan dan follow-up dan berfungsi sebagai penghubung antara sekolah dan organisasi masyarakat sehingga mereka dapat bekerja sama untuk membantu siswa (ASCA, 2013: 2).

Aktivitas melakukan kolaborasi konselor memerlukan pengetahuan dan ketrampilan untuk menunjang keterlaskanaan kolaborasi intern maupun ekstern. Dettmer, Dyck \& Thurston dalam Hidayat (2013) menawarkan sudut pandang lain dengan mengajukan pendekatan konsultan sekolah kolaboratif (collaborative school consultant) yang memerlukan keterampilan komunikasi fasilitatif konselor, hubungan kooperatif dengan personel sekolah, dan koordinasi layanan yang diperlukan.

Kegiatan utama konselor adalah koordinasi, konsultasi dan konseling. Koordinasi adalah bentuk pelayanan tidak langsung kepada siswa. Koordinasi adalah kegiatan prosedural organisasi dalam membantu konselor memahami maksud dan tujuan kegiatan yang dilakukan dan untuk menghindari tumpang tindih kecuali jika mereka (konselor) dengan sengaja merencanakan beberapa kegiatan. Kegiatan koordinasi mencakup semua area kegiatan seperti penjadwalan layanan, pemberian layanan, evaluasi, dan kegiatan terkait dalam program bimbingan dan konseling. (Myrick, 2011: 374)

Ketrampilan selanjutnya adalah kepemimpinan Kepemimpinan adalah keterampilan penting bagi konselor sekolah saat mereka mengembangkan dan mengelola program konseling sekolah yang komprehensif. Karena tema advokasi, kolaborasi dan perubahan sistemik lainnya memerlukan kepemimpinan sampai tingkat tertentu, kepemimpinan mungkin menjadi dasar dari keterampilan penting lainnya yang diperlukan untuk pelaksanaan program (Mason \& McMahon, dikutip ASCA 2013).

Dahir and Stone, (2012:173). Kepemimpinan untuk konselor sekolah sepenuhnya berpartisipasi sebagai bagian integral dari misi dan fungsi sekolah, mendukung setiap siswa untuk menjadi pelajar yang sukses, dan memungkinkan keberhasilan siswa.

Kepemimpinan untuk konselor sekolah memerlukan penggabungan dengan pendidik lain dan komunitas sekolah yang lebih besar untuk secara positif mempengaruhi kesempatan siswa harus menjadi pelajar yang sukses dan untuk 
mencapai standar yang tinggi. Kepemimpinan berarti memasuki kemitraan untuk menunjukkan komitmen untuk membantu kepala sekolah dan pemangku kepentingan internal dan eksternal lainnya memberikan tugas yang sangat penting untuk mendukung pembelajaran siswa

DeRoche (dikutip Dollarhide dan Saginak, 2011) mencantumkan hal berikut, yang telah kami adaptasikan yaitu peran pemimpin program bimbingan dan konseling sekolah yang komprehensif:

1. Visioner untuk arah masa depan untuk program, sekolah, dan peserta didik

2. Perancang dan penulis pernyataan misi untuk program bimbingan dan konseling di sekolah

3. Pengembangan konsensus untuk kepentingan program konseling sekolah, ranah perkembangan, dan nilai dan isi kurikulum perkembangan.

4. Penyedia informasi tentang program, sekolah, masalah perkembangan keluarga siswa, dan inovasi yang menarik bidang pendidikan, bimbingan, dan konseling

5. Pembawa standar untuk kualitas program konseling sekolah yang komprehensif, termasuk metode untuk membimbing dan menilai efektifitas pelaksanaan, pemeliharaan dan evaluasi

6. Perencana implementasi untuk program bimbingan dan konseling

7. Model peran untuk nilai dan pembelajaran kurikulum perkembangan

8. Pemandu risiko dan advokat untuk pengembangan semua siswa

9. Komunikator, berjalan program dilakukan komunikasi efektif dengan semua mitra yang terlibat

10. Kolaborator dalam upaya menerapkan program bimbingan dan konseling konseling yang komprehensif

11. Penyedia sumber daya, yang mungkin berbentuk bahan atau gagasan untuk mengintegrasikan kurikulum perkembangan ke kelas.

Keterampilan penting guru bimbingan dan konseling adalah manajemen waktu pelaksanaan layanan bimbingan dan konseling. Menurut Silver (dalam Cobia dan Henderson,2003), manajemen waktu adalah penting untuk organisasi yang baik. Konselor sekolah yang sudah mapan dan tujuan program prioritas sedang meletakkan dasar untuk manajemen waktu yang baik. Bliss (dalam Cobia dan Henderson,2003), menyarankan membagi tujuan ke tingkat prioritas berjenjang. Prioritas A-level yang penting dan mendesak (misalnya, siswa dalam krisis). Prioritas B-tingkat yang penting tapi tidak mendesak (misalnya, sebuah program yang direncanakan selama beberapa bulan lagi). Prioritas C-tingkat yang mendesak tetapi tidak penting.

Menurut ASCA (2012:43) memberikan rekemondasikan bahwa konselor sekolah mengalokasikan waktu layanan minimal $80 \%$ atau lebih pada komponen layanan direktif (layanan dasar, layanan responsif, dan layanan perencanaan individual) pada siswa. Sedang sisanya waktu $20 \%$ untuk aktivitas manajemen program dan dukungan sistem.

\section{SIMPULAN DAN SARAN}

Program Bimbingan dan konseling komprehensif didasarkan pada upaya pencapaian tugas perkembangan, pengembangan potensi, dan pengentasan masalah-masalah konseli. Tugastugas perkembangan dirumuskan sebagai standar kompetensi yang harus dicapai konseli, sehingga pendekatan ini disebut juga bimbingan dan konseling berbasis standar. Standar kompetensi siswa mengacu pada Standar Kompetens Kemandirian Peserta Didik (SKKPD) yang terbagi dalam 11 aspek perkembangan. Ketercapaian setiap aspek aspek perkembangan bukan pada lingkup aspeknya namun pada kualitas pencapaiannya.

Keberhasilan implementasi Program bimbingan dan konseling komprehensif yaitu terpenuhinya enam ciri yaitu holistik, sistematik, seimbang, proaktif, integrasi dalam kurukulum sekolah, dan refleksi. Prosedur dalam penyusunan program bimbingan dan konseling komprehensif adalah perencanaan (planning), pengorganisasian (organizing), penerapan (implementating), dan evaluasi (evaluation).

Implementasi program bimbingan dan konseling didukung oleh ketersediaan sumber daya manusia yang terampil. Guru bimbingan dan konseling/konselor diharapkan seperangkat pengetahuan dan ketrampilan yang mendukung keterlaksanaan program. Pengetahuan yang utuh tentang teori perkembangan. Ketrampilan yang dimiliki konselor adalah melakukan koordinasi dengan berbagai pihak dalam melaksanakan program bimbingan dan konseling. Konselor 
memiliki kepemimpinan yang kokoh dalam menjalankan program bimbingan. Menurut ASCA (2012:43) memberikan rekemondasikan bahwa konselor sekolah mengalokasikan waktu layanan minimal $80 \%$ atau lebih pada komponen layanan direktif (layanan dasar, layanan responsif, dan layanan perencanaan individual) pada siswa. Sedang sisanya waktu $20 \%$ untuk aktivitas manajemen program dan dukungan sistem

\section{DAFTAR RUJUKAN}

American School Counselor Association. (2012). ASCA national model: A framework for school counseling programs. American School Counselor Association.

Burkard, A., Gillen, M., Martinez, M., \& Skytte, S. (2012). Implementation challenges and training needs for comprehensive school counseling programs in Wisconsin high schools. Professional School Counseling, 16(2), 136-145.

Bhakti, C. P., Kumara, A. R., \& Safitri, N. E. (2017). Pemahaman guru bimbingan dan konseling tingkat SMP tentang bimbingan dan konseling komprehensif. Counsellia: Jurnal Bimbingan dan Konseling, 7(1), 1119.

Cobia, D. C., \& Henderson, D. A. (2003). Handbook of school counseling. Prentice Hall.

Dahir, C. A., \& Stone, C. B. (2012). The transformed school counselor. Brooks/Cole, Cengage Learning.

Daryono.2015. Model Program Bimbingan dan Konseling Komprehensif di SMA. Tesis. Universitas Negeri Yogyakarta: tidak diterbitkan.

Depdiknas. 2008. Penataan Pendidikan Profesional Konselor dan Layanan Bimbingan dan Konseling Dalam Jalur Pendidikan Formal. Jakarta : Depdiknas.

Dollarhide.2011. Comprehensive School Counseling Programs: K-12 Delivery Systems in Action (2nd Edition). Pearson

Fajar Santohadi.2010. Manajemen Binbingan dan Konseling Komprehensif. USD Press : Yogyakarta

Fathur Rahman.2012. Manajemen dan Pengembangan Program Bimbingan Konseling. Yogyakarta : Modul
Pendidikan dan Latihan Profesi Guru Rayon 111 Universitas Negeri Yogyakarta.

Gysbers, N.C. \& Henderson P. (2012). Developing and Managing Your School Guidance and Counseling Program Fifth Edition. Alexandria : American Counseling Assosiation.

Hasan, S. U. N., \& Bhakti, C. P. (2016). Guidance and Counselling: A Comparison between Indonesia and Malaysia.Scientific Journal of PPIUKM, 3(6), 267-271.

Hidayat, D. R. (2013). Bimbingan Konseling: Kesehatan Mental Di sekolah. Bandung: Remaja Rosda Karya.

Kumara, A.R.2015. Pemahaman Guru Bimbingan dan Konseling Terhadap Program Bimbingan dan Konseling Komprehensif di SMK Negeri seKabupaten Bantul.Jurnal Komprehensif., 2(1). 12-18

Martin,I., Carey.J., \& DeCoster,K. A National Study of The Current Status of State School Counseling Models.

Myrick, Robert D. 2011. Developmental Guidance and Counseling : A Practical Approach Fifth edition. Minneapolis : Educational Media Corporation.

No, P. 111. 2014. Bimbingan dan Konseling di Pendidikan Dasar dan Pendidikan Menengah.

Permendiknas No.27 Tahun 2008 tentang Standar Kualifikasi Akademik dan Kompetensi Konselor

Riskiyah, R. (2017). Implementasi Permen Dikbud No 111 Tahun 2014 Dan Implikasinya Terhadap Kompetensi Dan Uraian Tugas Guru Bimbingan \& Konseling. Jurnal Pendidikan (Teori dan Praktik), 2(1).

Schmidt, John J. 2008. Counseling in Schools : Comprehensive Programs of Responsive Service for All Student. Boston : Pearson.

Sugiyo.2014. Manajemen Bimbingan dan Konseling di Sekolah. Widya Karya : Semarang

Sunaryo Kartadinata.2011. Menguak Tabir Bimbingan dan Konseling sebagai Upaya Pedagogis. Bandung : UPI Press

Uman Suherman. 2011. Pembangun Karakter dan Budaya Bangsa Melalui Bimbingan Komprehensif Berbasis Nilai Alquran 
(Tinjauan Filosofis tentang Hakikat dan Peran Manusia). Pidato Pengukuhan Jabatan Guru Besar. Bandung : UPI

Young, A., \& Kaffenberger, C. (2011). The beliefs and practices of school counselors who use data to implement comprehensive school counseling programs. Professional School Counseling, 15(2), 67-76.

Wilkerson, K., Pérusse, R., \& Hughes, A. (2013). Comprehensive school counseling programs and student achievement outcomes: A comparative analysis of RAMP versus non-RAMP schools. Professional School Counseling, 16(3), 172-184. 